\title{
Reparative innovation for urban climate adaptation
}

\section{Vanesa Castán Broto, Linda Westman and Ping Huang}

\begin{abstract}
Scholars of climate urbanism have raised the conundrum that action to address the ongoing challenges of climate change in cities have distributional impacts, deepening existing inequalities. This challenge is related in part to the ideas of urban innovation that dominate climate responses. Disruptive innovations are directed towards the rupture of existing systems of knowledge, seeking to create new ways of looking at the problem. The emerging scholarship on climate urbanism suggests that measures to adapt to climate change in urban environments heeding a disruptive narrative have uneven impacts and too often disadvantage the most vulnerable communities. In this article, we ask what it means to look for reparative innovation for climate change adaptation instead. Reparative thought has influenced different debates on climate change adaptation and other issues related to social justice, from dealing with the aftermath of conflicts to engaging in reparative experiences to deal with trauma. Critical theory has also looked into reparation as a means to engage with reparative understandings of cultural objects and heritage. We argue for a focus on reparative innovation to open up alternative innovation frameworks that acknowledge existing material urban histories and engage with the multiple forms of knowledge within the urban experience that support climate adaptation.
\end{abstract}

Keywords: Urban adaptation, urban transformations, urban infrastructure, disruptive innovation, reparative innovation.

Notes on the authors:

Vanesa Castán Broto is Professor of Climate Urbanism at the University of Sheffield.

Linda Westman is a Post-doctoral Research Associate at the University of Sheffield.

Ping Huang is a Post-doctoral Research Associate at the University of Sheffield.

(C) The author(s) 2021. This is an open access article licensed under a

Creative Commons Attribution-NonCommercial-NoDerivs 4.0 Unported License 


\section{Introduction}

Adapting to climate change impacts in urban areas constitutes an enormous challenge for which resources and capacities are limited. Climate adaptation is critical in rapidly growing urban areas, with informal areas that lack appropriate services or rapidly growing peripheries where new infrastructures will be needed (Dodman et al. 2012, Satterthwaite et al. 2007). Adaptation creates new demands and new forms of thinking about social relations with the built environment and urban infrastructure.

Action for climate adaptation can have unintended impacts that exacerbate urban vulnerability (Anguelovski et al. 2016, Eriksen et al. 2021). In urban areas of less developed countries, adaptation outcomes are intertwined with histories of dispossession and colonisation, and raise questions of justice (Henrique \& Tschakert 2020, Rumbach 2017). Adaptation is a fundamentally political problem, but mainstream efforts tend to curtail political debate (North et al. 2017, Scoville-Simonds et al. 2020). For example, existing development programmes may be rebranded under the umbrella of adaptation without making a marked difference in addressing the marginalisation relations that underpin vulnerabilities (Schipper et al. 2020).

Climate urbanism refers to a growing wave of critiques about how cities have become central places to address climate change, both in terms of addressing climate impacts (adaptation) and reducing emissions (mitigation) (Castán Broto et al. 2020). Central to this body of scholarship is a concern with the impacts of climate action: creating a resilient city and resilient spaces often happens at the expense of disadvantaged populations because of the entrenched dynamics of capital accumulation and securitisation of spaces of privilege (Anguelovski et al. 2019a, 2019b, Long \& Rice 2019). Climate adaptation could conceivably become a form of strategic urbanism to address existing inequalities (Chu et al. 2017). Still, in practice, the negative impacts of climate action on vulnerable populations are apparent. For example, UN-Habitat reports that cities are increasingly concerned with new forms of inequality associated with climate action. Climate protection projects may add value to the urban environment at the expense of marginalised urban groups, that may be pushed out because of changing conditions of habitation, such as increases in housing prices and rents-a process known as climate gentrification (UN-Habitat 2020).

Climate urbanism interrogates whether there are alternatives to deliver urban climate action in a just manner (Robin \& Castán Broto 2020). Postcolonial analyses of urban infrastructure turn attention to do-it-yourself, makeshift, and place-based adaptations that can deliver new ways of thinking about infrastructure (Cloutier et al. 2018, Groulx et al. 2014, Udelsmann Rodrigues 2019). There are alternatives for climate change adaptation, particularly among urban citizens, but existing city-wide 
initiatives rarely incorporate them. One key issue is to notice and articulate place-based innovations into coherent climate policy. Innovations for adaptation often involve looking beyond highly technical systems of securitisation and control. Unlike mitigation proposals that emphasise the possibility of disrupting wider infrastructure and technological systems, adaptation calls for 'reparative innovations': that is, innovations focused on preserving adaptation capacities that address the city's past and future.

In this short article, we argue that thinking about adaptation innovations is crucial to addressing the challenges of inequality associated with climate urbanism. Our concept of reparative innovation builds upon queer theory and legal discussions of reparative justice. We further develop the concept of reparative innovation analytically, in contrast with ideas of disruption and disruptive innovation. In this way, the concept of reparative innovation brings concerns with justice to the core concepts of innovation studies. The paper concludes with a discussion of reparative innovation in the context of urban infrastructure development in postcolonial contexts. Our research agenda maps urban adaptation as a practice that must aim to be inherently reparative. A reparative understanding of innovation in urban adaptation helps reimagine adaptation actions beyond the circular debates on climate justice. Reparative innovations do not seek to disassemble the apparatus in which they are embedded, but they acknowledge and address past and present harm, making the apparatus liveable.

\section{The promises of reparative innovations}

Struggles for recognition have been part of environmental justice movements since their inception, concerned not only with the impacts of environmental change but also with the extent to which marginalised groups are excluded from their selfrealisaton and self-determination (Schlosberg 2004). Climate change adds a new dimension, but forces a re-examination of collective ideas of the future and who has a hand in shaping the trajectories to those futures. The struggle for recognition has led to an emphasis on restorative justice in environmental justice movements, as a framework that emphasises reconciliation (Figueroa \& Waitt 2010). Restorative justice is closely related to indigenous affective experiences of colonisation and decolonisation that offer transformative alternatives (Smith 2012). Restorative justice also invokes governmental responsibility for maintaining the restorative process and the conditions that make it possible, particularly in the context of criminal justice and, for example, environmental crimes (van Wormer \& Walker 2012). 
The notions of reparative justice and restorative justice are frequently used interchangeably: often, calls for restorative justice add the intention to repair. In this paper, however, we favour the notion of reparation and reparative justice because it allows a move away from formal processes to achieve justice, focusing instead on active efforts to engage with people and the world materially, through artefacts. This notion of reparative justice is a springboard to rethink innovation as a means to focus on creating new futures that climate adaptation requires. This is inspired by Linda Tuhiwai Smith (2012: 159), who refers to 'the spirit of creating that indigenous communities have exercised over thousands of years' as a means to 'dream new visions and to hold to old ones'. In a postcolonial world, reparative innovation celebrates a pluralism of knowledge that can inform climate adaptation.

Reparation is a multilayered concept that has to do with maintenance (fixing something) and making amends. That undercurrent of 'making amends' reveals that reparation relates to our relationship with others and the material world: it is about recognising having done something wrong, which needs payback for those people or things that have been wronged. Reparation thus implies an action to address the wrongs of the past:

To hold that redressing a wrong is an obligation of justice is to hold that some remedial action is (at least prima facie) necessary, something that morally must be done (Walker 2015: 211).

Walker explains that thinking about reparative justice is different from thinking about corrective justice. Reparation is not the same as paying for a deed. A compensation for unjust harms and losses will do little to repair the loss of your home - and your lifeafter flooding. For people living in informal settlements where their tenure depends on holding onto space, the enormous harm made by resettlement can hardly be accounted for by compensation. Walker examines reparative justice in the context of mass violence and systemic human rights abuses, but the lessons are relevant to understanding climate adaptation. Walker explains that practical experiences in reparative justice cast it as a process in-the-making that requires a certain degree of experimentation in discovering what constitutes justice. In conclusion, Walker argues that engaging with different methods can lead to that reparative discovery.

In the context of climate change, reparative justice calls for examining the history of climate change as a problem, as a means to attribute responsibilities for reparation. However, it follows that history alone is not sufficient and that, to a certain extent, a degree of responsibility for reparations must be widespread (Thompson 2021). Climate change is emerging as a profoundly traumatic event, particularly considering human culture's continuity (Brulle \& Norgaard 2019). Reparation is a necessary but not sufficient part of healing from trauma (Danieli 2009: 41-77). Reparations must 
both reduce carbon emissions and address their historical dimensions while also delivering adaptation and resilience to safeguard life.

An example of events that can inspire reparation thought in climate change adaptation is the legal struggle of indigenous peoples who suffered Canada's residential schools policy - a series of human rights violations committed over 150 years. Mahoney (2019: 207) explains that indigenous law 'framed the wide range of harms, empowered the victims to articulate what they wanted, justified individual and collective reparations, and laid the groundwork for a new relationship with the perpetrators' in the reparations in the Indian Residential School Settlement Agreement. Indigenous law provided an alternative to a colonial model of negotiation based on the principle of corrective justice. First Nations proposed instead measures rooted in indigenous law, such as restorative actions, the recognition of intergenerational harms, and establishing a truth commission (Mahoney 2019). The implications spread in time:

Reparation looks forward, signalling not only the concern of victims and survivors with monetary compensation but, just as importantly —as the word's root, 'repair,' indicates - with upholding dignity and recovering health in the wake of gross violations of human rights (Bonner \& James 2011).

By embracing reparative innovation in climate adaptation, we seek to bring these insights into approaches to address human vulnerabilities through knowledge-making and innovation.

Queer studies embrace a reparative impulse to enable positive attachments within a culture that rejects part of its members. Cultural theorist Eve Kosofsky Sedgwick interrogated the link between learning and positive outcomes. Sedgwick concluded that reparative impulses support people and communities to gain sustenance even within cultures that do not sustain them (Sedgwick 2003). Against criticisms that seek to anticipate the hidden meaning of everything, reparative readings situate the object of knowledge within a material history of multiple experiences and attachments (see also Hanson 2011, Wiegman 2014). We propose to rethink adaptation innovations as reparative both to accept the horrors of climate change and to provide a hopeful response to this urgent crisis. There are examples of how queer solidarities support urban resilience and responses to disasters that recognise all citizens as active agents rather than passive vulnerable groups (Wisner et al. 2017). With this paper we aim to extend this scholarship by redeploying the notion of reparation in the context of innovation for climate adaptation.

However, what such a reparative impulse could look like in the field of climate adaptation is not entirely clear. Here we propose to think of a reparative framework in relation to one of the most popular ideas to think about environmental innovation: disruptive innovation. 


\section{Reparative innovation as an alternative to disruptive innovation}

The concept of reparative innovation emerges in stark contrast with a better understood concept of disruptive innovation. Disruptive innovation seeks to alter a given market and technological context radically. The concept derives from the notion of creative destruction (Schumpeter 1942), which assumes that invention acts as a disruptive force that creates renewal (and 'progress') in economic systems. Entrepreneurs and inventors become agents of change, driving change throughout industries and society. Sustaining innovations introduce change incrementally. In contrast, disruptive innovations are low-cost, accessible technologies that produce sweeping and fundamental changes across markets (Christensen 2013). They establish new value propositions, change consumer behaviors, and displace incumbent firms. The concept of disruptive innovation emerged from a concern with strategic management options for corporations. According to an influential interpretation by Abernathy and Clark (1985), disruptive technologies are characterised by their qualitative differences in associated skill sets, resources, and competencies compared with established technologies. Thus, their diffusion and establishment render entire industrial systems obsolete.

The concept of disruptive innovation tends to have a narrow focus of technological change and may not always acknowledge the variety of ways in which innovation occurs (Markides 2006, McDowall 2018). Nevertheless, the idea of disruptive technology remains influential and widely used. It has become framed as a source of 'simpler, cheaper, easier to use' solutions that may effectively tackle pervasive social issues such as poverty or sustainability (Hart 2005). The emergence of new digital technologies has reignited disruptive innovation ideas to tackle resilience and sustainability problems (Nasiri et al. 2017, World Bank 2018). Likewise, disruptive innovation ideas inform research on business innovation and sustainability (Cohen \& Winn 2007, Dean \& McMullen 2007) and support the argument of mass-market transformations propelled by sustainable business models (Aminoff et al. 2017, Schaltegger et al. 2016).

In science and technology studies, disruptive innovations interrupt the operation of socio-technical systems, forcing a change in the configuration of social practices and material technologies. Socio-technological configurations appear as a regime that is semi-stable for the analyst. A transition happens when disruptive innovations find their way into that regime, forcing a realignment of social and material components. Crucial to these analyses is that disruption can be seen as a 'prerequisite of system reconfiguration', rendering the dynamic indispensable to transition processes (Kivimaa et al. 2021). Niche innovations can only be radical enough if driven by disruptive innovations that hold power to overthrow unsustainable socio-technical regimes (e.g., Johnstone et al. 2020, Tyfield 2011). 
Transition scholars argue that disruptive innovation fosters sustainability transitions. For example, renewable energy technologies are frequently framed as disruptive innovations that may challenge fossil-fuel-dependent production and consumption systems. Disruptive innovations in solar energy, for example, include customer-oriented solutions for batteries and photovoltaic (PV) power (Frankel \& Wagner 2017, Say et al. 2018), solar utilities (Eisen 2010), or PV systems (Frankel et al. 2014). But the range of disruptive innovations in the current infrastructure regime is varied, ranging from hydrogen fuel cells (Hardman et al. 2013) to sharing economy solutions (Schneider 2017). While these arguments are more familiar in debates about reducing carbon emissions, they are gaining traction in adaptation research concerning the disruptive force required to achieve resilience and transformation (Saxena et al. 2018). These connections become increasingly apparent in innovations that address mitigation and adaptation simultaneously: for example, off-grid renewable technologies (Sapkota et al. 2014) or flexible and modular infrastructure designs (Shakou et al. 2019).

While disruptive innovations may have a place in urban adaptation, a fundamental insight from transitions theory is that such disruptive innovations emerge within the dominant socio-technical system, and, hence, they do not necessarily challenge it (Bulkeley et al. 2014). The concept of disruptive innovation emerged from an interest in understanding incumbent strategies to manage threats from new technologies. The ensuing frameworks have remained geared towards analyses of industrial dynamics and changes in markets. Disruptive innovations are embedded in the incumbent's grammar (and, even more deeply, in the logic of political economies and the global capitalist system). In that sense, the promise of disruption is misleading. Changing the system fundamentally is not the objective of disruptive technology. In summary, the link between abstract ideas of disruptive innovation and the question of urban resilience is fraught. Reparative innovation provides an alternative angle of looking, a different way of engaging with the question of innovation that may be more attuned to the demands of adaptation in urban areas.

\section{Finding hope in the reparative}

Unlike narratives of disruptive innovation, reparative innovations emerge from a profound recognition of specific social and cultural histories - including hegemonic narratives of capitalist extractivism and colonial domination - that shape the context of adaptation action. In urban environments, adaptation depends on the interactions with multiple infrastructure systems and variegated impacts of different types of disasters, from heat to flooding (Gough et al. 2019). Urban infrastructure landscapes 
are constituted through governance cultures, resource flows, and everyday life practices (Castán Broto 2019). Infrastructure is implicated in urban resilience and the creation of livable urban spaces in complex ways (Petrescu et al. 2020). It shapes urban practices at different levels:

Infrastructure is food production and the social-technical relationships that it entails. Infrastructure is about the ways in which seeds and credit circulate and how water is distributed; it is about how planting and harvesting are practised; it is about who can grow what where, about who is able to make a call on land for the purposes of food growing. Infrastructure is always part of a bigger matrix, as this and a number of other projects reveal. What exactly infrastructure connects and how it does so are important questions that can be answered contextually (Knowles 2019: 5).

From this reading, reparative innovations emerge as embedded in collective urban histories. Urban histories are not linear but complex and multilayered, as people's lives intersect in different planes, alongside ecosystems and technologies. Reparative technologies first acknowledge those socio-ecological, profoundly material, histories as a means to draw the space of innovation. Through experimentation with those landscapes, a wide range of adaptation possibilities emerges, linked in every case to situated perceptions of a place and its history.

Nevertheless, there is increasingly a consensus that adaptation depends on large societal transformations (Patterson et al. 2017), transformations dependent on multiple social and technological innovations and with likely uneven impacts in urban environments. Transition theory and ideas of disruptive innovations have been used to understand such transformations (Dixon et al. 2014). However, transition theory does not account for the spatial conditions of innovation and technological 'disruption'. Whether a given technology will suit an urban environment depends on multiple conditions of urban governance, the history of the city and its imprint in the built environment, and the cultural and social practices of technological use (Huang \& Castán Broto 2018).

For example, a recent study compared how people reconstructed their houses after Typhoon Haiyan landed in Central Philippines in 2013 and after the Gorkha Earthquake in Nepal in 2015. The study casts self-recovery as inevitable and a process that can be harnessed to build resilience (Schofield et al. 2019). However, policy and planning can work against bottom-up efforts to build urban resilience. The comparative study mentioned above found that policy decisions to improve housing safety often had negative consequences for people's lives. Resettlement decisions separated families from the crucial networks that supported their livelihoods. Conditional cash grants raised prices, reducing the affordability of construction materials and labour. 
Adaptation calls for nimbler technologies adapted to specific conditions and policies that recognise the trajectories in which adaptation occurs. Ideas of transition and associated accounts of disruptive innovation do not provide a spatially sensitive version of technological change in urban areas. Reparative innovation, as we explain below, seeks to engage with the existing capacities of a given place, assembling resources at hand to create new possibilities for adaptation.

Reparative innovation endorses an alternative reading of the process of change, one that recognises radical change as the unexpected product of long-term, uncoordinated shifts. In the project Low Carbon Action in Ordinary Cities, funded by the European Research Council, we are currently compiling examples of what such reparative innovations look like. In the infrastructure context of less developed urban areas, where informality is the norm, reparative innovation calls for positive imaginations of collective urban futures that also acknowledge difficult histories of colonial exploitation and resource extractivism.

In the city of Tasikmalaya in Indonesia, farmers make waterwheels out of bamboo to cope with drought. The bamboo waterwheels function to drive water from a local river to the withering farms. Tasikmalaya has a long tradition of bamboo culture, represented by the bamboo weaving crafts (Triharini 2014). As a native material, bamboo is widely used by local people in social practices such as building houses and making furniture. In this case, with extremely limited resources, local farmers use the native material to reduce drought impacts. This is a practice that involves craftsmanship as a means for ecological restoration. Rather than revolutionise water management, the challenge is integrating human skills and natural materials to manage the changing patterns of drought. Bamboo craft is physical but also culturally embedded in traditional techniques and a rich heritage of weaving patterns. There is a fundamental emotional component that accompanies bamboo craftsmanship, and that becomes embedded in local adaptation practices. What is the adaptation value of such practice? We hardly know because few evaluations consider this kind of craftsmanship as adaptation. Nevertheless, there is a promise in innovations that build resilience incrementally.

Reparative innovation follows material experimentation that emerges from a close reading of the urban landscape. In the city of Abakaliki in Nigeria, a young engineer named Anthony Okafor built a solar-powered tricycle. Known locally as Keke Napep, the tricycle is one of the most widely used means of transportation in Nigeria. Commonly powered by petrol or diesel, Keke Napep is highly polluting and dangerous. In this case, the young engineer's innovation of a solar-powered Keke Napep is reparative-building on the possibilities of a given context. As Keke Napep is central to local people's commuting practices, a solar-powered one could constitute a nimble solution to facilitate mobility. Moreover, a solar-powered Keke Napep can reconfigure multiple layers of operation of transport systems, as charging - rather than fueling- 
becomes the primary demand. This reconfiguration does not need to be disruptive, market oriented, or policy driven.

Financialisation and the securitisation of urban spaces at the expense of vulnerable populations are increasingly the dominant accounts of climate change adaptation in urban areas. However, adaptation is most urgent in informal settlements lacking infrastructure, where disasters are compounded with structural inequalities. Innovations will no doubt be needed to catalyse a transformation to urban resilience. However, their eventual impacts will depend not only on the innovations themselves but also on how the innovation processes are conceived. This essay presents the idea of reparative innovation to rethink alternatives for urban adaptation that, rather than disrupting existing infrastructure systems, seek to engage with the political possibilities of situated knowledges and ecologies.

\section{Acknowledgements}

This article is part of the project Low Carbon Action in Ordinary Cities, a project that has received funding from the European Research Council (ERC) under the European Union's Horizon 2020 research and innovation programme Grant Agreement No 804051-LO-ACT-ERC-2018-STG.

\section{References}

Abernathy, W.J. \& Clark, K.B. (1985), 'Innovation: Mapping the Winds of Creative Destruction', Research Policy, 14(1): 3-22. https://doi.org/10.1016/0048-7333(85)90021-6

Aminoff, A., Valkokari, K., Antikainen, M. \&Kettunen, O. (2017), 'Exploring Disruptive Business Model Innovation for the Circular Economy', in International Conference on Sustainable Design and Manufacturing (Berlin, Springer), 525-36. https://doi.org/10.1007/978-3-319-57078-5_50

Anguelovski, I., Shi, L., Chu, E., Gallagher, D., Goh, K., Lamb, Z., Reeve, K. \& Teicher, H. (2016), 'Equity Impacts of Urban Land Use Planning for Climate Adaptation: Critical Perspectives from the Global North and South', Journal of Planning Education and Research, 36(3): 333-48. https://doi.org/10.1177/0739456X16645166

Anguelovski, I., Connolly, J.J., Pearsall, H., Shokry, G., Checker, M., Maantay, J., Gould, K., Lewis, T., Maroko, A. \& Roberts, J.T. (2019a), 'Opinion: Why Green "Climate Gentrification” Threatens Poor and Vulnerable Populations', Proceedings of the National Academy of Sciences, 116(52): 26139-43. https://doi.org/10.1073/pnas.1920490117

Anguelovski, I., Irazábal-Zurita, C. \& Connolly, J.J.T. (2019b), 'Grabbed Urban Landscapes: Sociospatial Tensions in Green Infrastructure Planning in Medellín', International Journal of Urban and Regional Research, 43(1): 133-56. https://doi.org/10.1111/1468-2427.12725

Bonner, M. \& James, M. (2011), 'The Three R's of Seeking Transitional Justice: Reparation, Responsibility, and Reframing in Canada and Argentina', International Indigenous Policy Journal, 2(3): 1-29. https://doi.org/10.18584/iipj.2011.2.3.3 
Brulle, R.J. \& Norgaard, K.M. (2019), 'Avoiding Cultural Trauma: Climate Change and Social Inertia', Environmental Politics, 28(5): 886-908. https://doi.org/10.1080/09644016.2018.1562138

Bulkeley, H.A., Castán Broto, V. \& Edwards, G.A. (2014), An Urban Politics of Climate Change: Experimentation and the Governing of Socio-technical Transitions (Abingdon, Routledge). https://doi.org/10.4324/9781315763040

Castán Broto, V. (2019), Urban Energy Landscapes (Cambridge, Cambridge University Press). https://doi.org/10.1017/9781108297868

Castán Broto, V., Robin, E., \& While, A., (2020) Climate Urbanism: Towards a Critical Research Agenda (Cham, Palgrave Macmillan). https://doi.org/10.1007/978-3-030-53386-1

Christensen, C.M. (2013), The Innovator's Dilemma: When New Technologies Cause Great Firms to Fail (Cambridge, MA, Harvard Business Review Press).

Chu, E., Anguelovski, I. \& Roberts, D. (2017), 'Climate Adaptation as Strategic Urbanism: Assessing Opportunities and Uncertainties for Equity and Inclusive Development in Cities', Cities, 60: 378-87. https://doi.org/10.1016/j.cities.2016.10.016

Cloutier, G., Papin, M. \& Bizier, C. (2018) 'Do-it-yourself (DIY) Adaptation: Civic Initiatives as Drivers to Address Climate Change at the Urban Scale', Cities, 74: 284-91. https://doi.org/10.1016/j.cities.2017.12.018

Cohen, B. \& Winn, M.I. (2007), 'Market Imperfections, Opportunity and Sustainable Entrepreneurship', Journal of Business Venturing, 22(1): 29-49. https://doi.org/10.1016/j.jbusvent.2004.12.001

Danieli, Y. (2009), Massive Trauma and the Healing Role of Reparative Justice, Reparations for Victims of Genocide, War Crimes and Crimes Against Humanity (Leiden, Brill Nijhoff).

Dean, T.J. \& McMullen, J.S. (2007), 'Toward a Theory of Sustainable Entrepreneurship: Reducing Environmental Degradation Through Entrepreneurial Action', Journal of Business Venturing, 22(1): 50-76. https://doi.org/10.1016/j.jbusvent.2005.09.003

Dixon, T., Eames, M., Britnell, J., Watson, G.B. \& Hunt, M. (2014), 'Urban Retrofitting: Identifying Disruptive and Sustaining Technologies Using Performative and Foresight Techniques', Technological Forecasting and Social Change, 89: 131-44. https://doi.org/10.1016/j.techfore.2013.08.027

Dodman, D., Bicknell, J. \& Satterthwaite, D. (2012), Adapting Cities to Climate Change: Understanding and Addressing the Development Challenges (Abingdon, Routledge). https://doi.org/10.4324/9781849770361

Eisen, J.B. (2010), 'Can Urban Solar Become a Disruptive Technology: The Case for Solar Utilities', Notre Dame Journal of Law, Ethics \& Public Policy, 24: 53-98.

Eriksen, S., Schipper, E.L.F., Scoville-Simonds, M., Vincent, K., Adam, H.N., Brooks, N., Harding, B., Lenaerts, L., Liverman, D. \& Mills-Novoa, M. (2021), 'Adaptation Interventions and their Effect on Vulnerability in Developing Countries: Help, Hindrance or Irrelevance?', World Development, 141: 105383. https://doi.org/10.1016/j.worlddev.2020.105383

Figueroa, R.M. \& Waitt, G. (2010), 'Climb: Restorative Justice, Environmental Heritage, and the Moral Terrains of Uluru-Kata Tjuta National Park', Environmental Philosophy, 7(2):135-64. https://doi.org/10.5840/envirophil20107219

Frankel, D. \& Wagner, A. (2017), 'Battery Storage: The Next Disruptive Technology in the Power Sector', McKinsey. https://www. mckinsey. com/business-functions/sustainability-andresource-productivity/our-insights/battery-storage-the-next-disruptive-technology-in-the-powersector

Frankel, D., Ostrowski, K. \& Pinner, D. (2014), 'The Disruptive Potential of Solar Power', McKinsey Quarterly, 2: 50-5. 
Gough, K.V., Yankson, P.W.K., Wilby, R.L., Amankwaa, E.F., Abarike, M.A., Codjoe, S.N.A., Griffiths, P.L., Kasei, R., Kayaga, S.\& Nabilse, C.K. (2019), 'Vulnerability to Extreme Weather Events in Cities: Implications for Infrastructure and Livelihoods', Journal of the British Academy, 7(s2): 155-81..

Groulx, M., Lewis, J., Lemieux, C. \& Dawson, J. (2014), 'Place-based Climate Change Adaptation: A Critical Case Study of Climate Change Messaging and Collective Action in Churchill, Manitoba', Landscape and Urban Planning, 132: 136-47. https://doi.org/10.1016/j.landurbplan.2014.09.002

Hanson, E. (2011), 'The Future's Eve: Reparative Reading after Sedgwick', South Atlantic Quarterly, 110(1): 101-19. https://doi.org/10.1215/00382876-2010-025

Hardman, S., Steinberger-Wilckens, R. \& Van Der Horst, D. (2013), 'Disruptive Innovations: The Case for Hydrogen Fuel Cells and Battery Electric Vehicles', International Journal of Hydrogen Energy, 38(35): 15438-51. https://doi.org/10.1016/j.ijhydene.2013.09.088

Hart, S.L. (2005), 'Innovation, Creative Destruction and Sustainability', Research-Technology Management, 48(5): 21-7. https://doi.org/10.1080/08956308.2005.11657334

Henrique, K.P. \& Tschakert, P. (2020), 'Pathways to Urban Transformation: From Dispossession to Climate Justice', Progress in Human Geography, online first, 0309132520962856. https://doi.org/10.1177/0309132520962856

Huang, P. \& Castán Broto, V. (2018), 'Interdependence Between Urban Processes and Energy Transitions: The Dimensions of Urban Energy Transitions (DUET) Framework', Environmental Innovation and Societal Transitions, 28: 35-45. https://doi.org/10.1016/j.eist.2018.03.004

Johnstone, P., Rogge, K.S., Kivimaa, P., Fratini, C.F., Primmer, E. \& Stirling, A. (2020), 'Waves of Disruption in Clean Energy Transitions: Sociotechnical Dimensions of System Disruption in Germany and the United Kingdom', Energy Research \& Social Science, 59: 101287. https://doi.org/10.1016/j.erss.2019.101287

Kivimaa, P., Laakso, S., Lonkila, A.\& Kaljonen, M. (2021), 'Moving Beyond Disruptive Innovation: A Review of Disruption in Sustainability Transitions', Environmental Innovation and Societal Transitions, 38: 110-126. https://doi.org/10.1016/j.eist.2020.12.001

Knowles, C. (2019), 'Cities and Infrastructure in the Global South: Introduction', Journal of the British Academy, 7(s2): 1-10. https://doi.org/10.4337/9781788971713.00007

Long, J. \& Rice, J.L. (2019), 'From Sustainable Urbanism to Climate Urbanism', Urban Studies, 56(5): 992-1008. https://doi.org/10.1177/0042098018770846

Mahoney, K. (2019), 'Indigenous Legal Principles: A Reparation Path for Canada's Cultural Genocide', American Review of Canadian Studies, 49(2): 207-30. https://doi.org/10.1080/02722011.2019.1626099

Markides, C. (2006), 'Disruptive Innovation: In Need of Better Theory', Journal of Product Innovation Management, 23(1): 19-25. https://doi.org/10.1111/j.1540-5885.2005.00177.x

McDowall, W. (2018), 'Disruptive Innovation and Energy Transitions: Is Christensen's Theory Helpful?', Energy Research \& Social Science, 37: 243-6. https://doi.org/10.1016/j.erss.2017.10.049

Nasiri, M., Tura, N. \& Ojanen, V. (2017), 'Developing Disruptive Innovations for Sustainability: A Review on Impact of Internet of Things (IOT)', 2017 Portland International Conference on Management of Engineering and Technology (PICMET). IEEE. https://doi.org/10.23919/PICMET.2017.8125369

North, P., Nurse, A. \& Barker, T. (2017), 'The Neoliberalisation of Climate? Progressing Climate Policy under Austerity Urbanism', Environment and Planning A: Economy and Space, 49(8): 1797-815. https://doi.org/10.1177/0308518X16686353

Patterson, J., Schulz, K., Vervoort, J., Van Der Hel, S., Widerberg, O., Adler, C., Hurlbert, M., Anderton, K., Sethi, M. \& Barau, A. (2017), 'Exploring the Governance and Politics of Transformations Towards Sustainability', Environmental Innovation and Societal Transitions, 24: 1-16. https://doi.org/10.1016/j.eist.2016.09.001 
Petrescu, D., Petcou, C., Safri, M. \& Gibson, K. (2020), 'Calculating the Value of the Commons: Generating Resilient Urban Futures', Environmental Policy and Governance, 31(3): 159-74. https://doi.org/10.1002/eet.1890

Robin, E. \& Broto, V.C. (2020), 'Towards a Postcolonial Perspective on Climate Urbanism', International Journal of Urban and Regional Research, 45(5): 869-78. https://doi.org/10.1111/1468-2427.12981

Rumbach, A. (2017), 'At the Roots of Urban Disasters: Planning and Uneven Geographies of Risk in Kolkata, India', Journal of Urban Affairs, 39(6): 783-99. https://doi.org/10.1080/07352166.2017.1282771

Sapkota, A., Lu, Z., Yang, H. \& Wang, J. (2014), 'Role of Renewable Energy Technologies in Rural Communities' Adaptation to Climate Change in Nepal', Renewable Energy, 68: 793-800. https://doi.org/10.1016/j.renene.2014.03.003

Satterthwaite, D., Huq, S., Pelling, M., Reid, H. \& Romero Lankao, P. (2007), 'Adapting to Climate Change in Urban Areas: The Possibilities and Constraints in Low- and Middle-income Nations, working paper, IIED. https://pubs.iied.org/sites/default/files/pdfs/migrate/10549IIED.pdf

Saxena, A., Qui, K. \& Robinson, S.-a. (2018), 'Knowledge, Attitudes and Practices of Climate Adaptation Actors Towards Resilience and Transformation in a 1.5 C World', Environmental Science \& Policy, 80: 152-9. https://doi.org/10.1016/j.envsci.2017.11.001

Say, K., John, M., Dargaville, R. \& Wills, R.T. (2018), 'The Coming Disruption: The Movement Towards the Customer Renewable Energy Transition', Energy Policy, 123: 737-48. https://doi.org/10.1016/j.enpol.2018.09.026

Schaltegger, S., Lüdeke-Freund, F. \& Hansen, E.G. (2016), 'Business Models for Sustainability: A Co-evolutionary Analysis of Sustainable Entrepreneurship, Innovation, and Transformation', Organization \& Environment, 29(3): 264-89. https://doi.org/10.1177/1086026616633272

Schipper, E.L.F. \& Tanner, T., Dube, O.P., Adams, K.M. \& Huq, S. (2020), 'The Debate: Is Global Development Adapting to Climate Change?', World Development Perspectives, 18(C). https://doi.org/10.1016/j.wdp.2020.100205

Schlosberg, D. (2004), 'Reconceiving Environmental Justice: Global Movements and Political Theories', Environmental Politics, 13(3): 517-40. https://doi.org/10.1080/0964401042000229025

Schneider, H. (2017), Creative Destruction and the Sharing Economy: Uber as Disruptive Innovation (Cheltenham, Edward Elgar).https://doi.org/10.4337/9781786433435

Schofield, H., Lovell, E., Flinn, B. \& Twigg, J. (2019), 'Barriers to Urban Shelter Self-recovery in Philippines and Nepal: Lessons for Humanitarian Policy and Practice', Journal of the British Academy, 7(s2): 83-109.

Schumpeter, J.A. (1942) Capitalism, Socialism and Democracy (London, Routledge).

Scoville-Simonds, M., Jamali, H. \& Hufty, M. (2020), 'The Hazards of Mainstreaming: Climate Change Adaptation Politics in Three Dimensions', World Development, 125: 104683. https://doi.org/10.1016/j.worlddev.2019.104683

Sedgwick, E.K. (2003), Paranoid Reading and Reparative Reading, Or, You're So Paranoid, You Probably Think This Essay Is About You, Touching Feeling-Affect, Pedagogy, Performativity (Durham, NC, Duke University Press).

Shakou, L.M., Wybo, J.-L., Reniers, G. \& Boustras, G. (2019), 'Developing an Innovative Framework for Enhancing the Resilience of Critical Infrastructure to Climate Change', Safety Science, 118: 364-78. https://doi.org/10.1016/j.ssci.2019.05.019

Smith, L.T. (2012), Decolonizing Methodologies: Research and Indigenous Peoples 2nd edn (London, Zed Books)

Thompson, J. (2021), 'Taking Responsibility for the Past: Does Reparative Justice Apply to the Emissions of Past Generations?', ABC Religion \& Ethics, 9 February. https://www.abc.net.au/ religion/janna-thompson-reparative-justice-and-climate-change/13137592 
Triharini, M. (2014), 'Preserving Tradition in Craft Design Development (Case Studies: Yamanaka Lacquerware, Japan and Tasikmalaya Bamboo Weaving, Indonesia)'. https://www.academia.edu/38595438/Preserving_Tradition_in_Craft_Design_Development

Tyfield, D. (2011), 'Food Systems Transition and Disruptive Low Carbon Innovation: Implications for a Food Security Research Agenda', Journal of Experimental Botany, 62(11): 3701-6. https://doi.org/10.1093/jxb/err123

Udelsmann Rodrigues, C. (2019), 'Climate Change and DIY Urbanism in Luanda and Maputo: New Urban Strategies?', International Journal of Urban Sustainable Development, 11(3): 319-31. https://doi.org/10.1080/19463138.2019.1585859

UN-Habitat (2020), World Cities Report 2020: The Value of Sustainable Urbanization. (Nairobi, UN-Habitat). https://unhabitat.org/World\%20Cities\%20Report $\% 202020$

van Wormer, K.S. \&Walker, L. (2012), Restorative Justice Today: Practical Applications (London, SAGE). https://doi.org/10.4135/9781452244228

Walker, M.U. (2015), 'Making Reparations Possible: Theorizing Reparative Justice', in C. Corradetti, N. Eisikovits \& J. Volpe Rotondi (eds) Theorizing Transitional Justice (Farnham, Ashgate), 211-22.

Wiegman, R. (2014), 'The Times We're in: Queer Feminist Criticism and the Reparative "Turn”, Feminist Theory, 15(1): 4-25. https://doi.org/10.1177/1464700113513081a

Wisner, B., Berger, G. \& Gaillard, J.C. (2017), 'We've Seen the Future, and It's Very Diverse: Beyond Gender and Disaster in West Hollywood, California', Gender, Place \& Culture, 24(1): 27-36. https://doi.org/10.1080/0966369X.2016.1204995

World Bank (2018), 'Disruptive Technologies and the World Bank Group Creating OpportunitiesMitigating Risks', Joint Ministerial Committee of the Boards of Governors of the Bank and the Fund on the Transfer of Real Resources to Developing Countries. https://www.devcommittee. org/sites/dc/files/download/Documents/2018-09/DC2018-0010\%20Disruptive\%20Technologies. pdf

To cite the article: Vanesa Castán Broto, Linda Westman and Ping Huang (2021), 'Reparative innovation for urban climate adaptation', Journal of the British Academy, 9(s9): 205-218.

DOI https://doi.org/10.5871/jba/009s9.205

Journal of the British Academy (ISSN 2052-7217) is published by The British Academy, 10-11 Carlton House Terrace, London, SW1Y 5AH www.thebritishacademy.ac.uk 